\title{
Effect of Fire on Microarthropods in New Zealand Indigenous Grassland
}

\author{
Barbara I. P. Barratt, ${ }^{1}$ Peter A. Tozer, ${ }^{2}$ Robin L. Wiedemer, ${ }^{3}$ \\ Colin M. Ferguson, ${ }^{4}$ and Peter D. Johnstone ${ }^{5}$ \\ Authors are ${ }^{1}$ Senior Scientist, ${ }^{2}$ Research Assistant, ${ }^{3}$ Research Assistant, ${ }^{4}$ Research Scientist, and \\ ${ }^{5}$ Senior Biometrician, AgResearch Invermay, Private Bag 50034, Mosgiel, New Zealand
}

\begin{abstract}
Indigenous tussock grassland in New Zealand has a history of extensive pastoralism, and burning has been used to remove litter to improve establishment of aerially oversown pasture species and to promote palatable tussock growth for livestock. In recent years, considerable areas of tussock grassland have been retired from grazing and formally protected. Conservation land managers, as well as farmers, require information on the impacts of both managed burns carried out in spring and accidental fires that usually occur in warmer, drier conditions in summer. This study investigated the impact of spring and summer tussock grassland burning on the predominant soil microarthropods, Collembola and Acari, at 2 sites in Otago, in the South Island of New Zealand. Quantitative sampling was carried out before and for up to 26 months after burning replicated 1-ha plots. Total density of microarthropods in unburnt plots covered a similar range at both sites with an average over 3 years of about $18000-$ $20000 \cdot \mathrm{m}^{-2}$ at each site. Both sites shared a dominance of Mesostigmata and Oribatida (Acari) and Isotomidae (Collembola). Burning in spring reduced densities of Oribatida after treatment at both sites for the duration of the study. However, after initial postburn reductions in density, populations of Isotomidae and Poduroidea (Collembola) recovered in the second year after burning. Prostigmata (Acari) appeared to be unaffected by fire. The effects of spring and summer grassland fires on microarthropod densities were rarely different. It was concluded that longer-term sampling would be required to observe the full recovery period for microarthropod populations after fire but that results from this study indicate rapid recovery of some microfaunal populations after fire, which is not strongly influenced by seasonal effects.
\end{abstract}

\section{Resumen}

Los pastizales amacollados nativos de Nueva Zelanda tienen una historia de apacentamiento extensivo, y la quema ha sido usada para remover el mantillo para mejorar el establecimiento de especies forrajeras sembradas en forma aérea y promover el crecimiento del pasto amacollado mas apetecible para el ganado. En años recientes considerables extensiones de pastizales amacollados han sido retiradas del apacentamiento y formalmente protegidas. Los manejadores para la conservación de la tierra, así como los ganaderos, requieren de información del impacto del fuego prescrito realizado tanto en primavera como de los ocurridos accidentalmente, los cuales usualmente se presentan en las condiciones calientes y secas de verano. Este estudio investigó el impacto de la quema de pastizales amacollados en primavera y verano sobre los microartropodos predominantes del suelo, Collembola y Acari, en dos sitios en Otago, en la Isla Sur de Nueva Zelanda. Se realizó un muestreo cuantitativo antes y 26 meses después de quemar parcelas repetidas de 1 ha. La densidad total de microartropodos en parcelas sin quemar tuvo un rango similar en ambos sitios, con un promedio de tres años de aproximadamente $18000-20000 \cdot \mathrm{m}^{-2}$ en cada sitio. Ambos sitios compartieron la dominancia de Mesostigmata y Oribatida (Acari) e Isotomidae (Collembola). La quema en primavera redujo las densidades de Oribatida después del tratamiento, lo que ocurrió en ambos sitios durante la duración de la investigación. Sin embargo, después de reducciones iniciales de densidad posteriores al fuego, las poblaciones de Isotomidae y Poduroidea (Collembola) se recuperaron en el segundo año después de la quema. Prostigmata (Acari) pareció no ser afectado por el fuego. Los efectos de la quema de los pastizales en primavera y verano sobre las densidades de microartropodos raramente fueron diferentes. Se concluyó que se podría requerir un plazo de muestreo a más largo para observar el periodo de recuperación total de las poblaciones de microartropodos después del fuego, pero los resultados de este estudio indican una rápida recuperación de algunas poblaciones microfaunales después del fuego lo cual no es fuertemente influenciado por los efectos de la época.

Key Words: Acari, mites, Collembola, springtails, population density, indigenous grassland, fire

\section{INTRODUCTION}

Research was funded by Landcare Research, the New Zealand Foundation for Research Science and Technology, and the New Zealand Department of Conservation.

Correspondence: Dr Barbara Barratt, AgResearch Invermay, Private Bag 50034, Mosgiel, New Zealand. Email: barbara.barratt@agresearch.co.nz

Manuscript received 5 November 2005; manuscript accepted 1 May 2006.
Grasslands cover almost $60 \%$ of New Zealand's land area (Wardle 1991), and about two-thirds of this comprises modified indigenous short- and tall-tussock grassland communities. The physical and biotic characteristics of indigenous grasslands in New Zealand has been reviewed in detail (Mark 1993). Upland 
grasslands are dominated by tussock-forming grass species, especially those in the genus Chionochloa. The intertussock flora is diverse, comprising herbs, small shrubs, mosses, and lichens. Tussock grasslands at lower altitudes throughout New Zealand are characterized by summer droughts, although on a global scale, depending on which climatic classification is used, Central Otago grassland is categorized as "cold temperate with no dry season" or "arid, with a cold season" aligning most closely with grasslands in northern China, Argentina, and North America (Coupland 1992). However, winter temperatures would be less severe than on these continental landmasses, rarely reaching below $-15^{\circ} \mathrm{C}$ (Mark 1993).

Indigenous tussock grassland characteristic of the lower rainfall hill and high country areas in the South Island of New Zealand is used for extensive pastoralism (Floate 1992). European settlers from the late 19th century used fire extensively to facilitate movement of grazing animals and to convert native grassland to improved pasture. Part of current farm management practice in these areas is to periodically burn in spring when conditions are relatively cool and the soil and vegetation are moist. Burning promotes new tussock growth, which is palatable to stock. Burning also serves to remove litter to increase the success of aerial oversowing with introduced legumes and grasses (Lowther and Douglas 1992). Conservationists, however, are concerned that fire damages native biota, allows weeds to establish, and promotes soil erosion (Payton and Pearce 2001). Overuse of fire in tussock grassland was eventually recognized as causing loss of tall tussock species, which were replaced by short tussock species or invasive weeds such as Hieracium (Aspinal 2001). Local agencies with responsibility for promoting sustainable land use have pointed out that burning tussock grassland can accelerate soil erosion and reduce soil quality, change vegetation characteristics, reduce conservation values and habitats for flora and fauna, and reduce water yield.

In recent years, considerable areas of tussock grassland have been retired from grazing and formally protected. This has taken place gradually since 1983 as a result of the Protected Natural Area Program, which sought to protect representative vegetation types from 85 biogeographic areas (ecological regions) across the country (McEwen 1987). Currently, as a result of the crown pastoral tenure review (Crown Pastoral Land Act 1998), areas of rangeland, particularly at higher altitudes, are being retired from grazing and managed in such a way that the natural character and the indigenous biodiversity will to some extent be restored. Information on the impact of fire on the conservation values of tussock grassland is required so that land managers can make decisions on appropriate management for these areas, recognizing that fire is a management option in some circumstances.

Research on the impacts of fire on invertebrates in grassland environments worldwide have shown few consistent patterns (Tscharntke and Greiler 1995; Friend 1996; Blanche et al. 2001), responses to fire depending on seasonal and environmental factors, and the interaction of these on the ecological requirements of the fauna. Warren et al. (1987) and Webb (1994) attributed reductions in densities of some arthropods to the reduced levels of soil moisture and changes in microclimate that follow removal of the litter layer.

In New Zealand there have been several studies undertaken on the impact of tussock burning on plant communities (e.g.,
O’Connor and Powell 1963; Mark 1965; Payton et al. 1986), but comparatively little has been published on the effect of indigenous grassland burning on invertebrates, particularly microarthropods. In one such study, Yeates and Lee (1997) found that densities of both mites and Collembola from litter and to 2 -cm soil depth were about $50 \%$ of those of an adjacent unburnt area 18 months after a spring burn, but after 30 months the densities of these groups was $<10 \%$ of that of unburnt areas. Many authors have found, not unexpectedly, that litter-dwelling invertebrates are more severely impacted by fire than those living deeper in the soil profile (e.g., HenigSever et al. 2001) and showed that inhabitants of the litter layer might be useful ecological indicators of fire intensity on ecosystems.

Collembola and Acari (mites) make up about $90 \%$ of the microarthropods in most soil systems (Coleman et al. 2004). They are important components of the soil fauna, both numerically and functionally in almost all terrestrial ecosystems, playing a major role in decomposition and in soil microstructure formation (Rusek 1998). Collembola are known mainly as generalist fungivores and detritivores, with some herbivores (e.g., Sminthuridae), but recent research using nitrogen stable isotope ratios has shown that they occupy a range of trophic niches (Chahartaghi et al. 2005). Mites comprise a diversity of functional groups, including predators, herbivores, fungivores, and detritivores. Both Collembola and mites are often present in undisturbed grassland at densities of up to $100000 \cdot \mathrm{m}^{-2}$ (Curry 1987a) and, in some ecosystems, up to several million per square meter (Rusek 1998).

The location of 2 sites for this study was selected on the basis of their relatively undisturbed soils (no history of cultivation) and "naturalness" of the vegetation. Both sites had experienced fires in their post-European history but had not been burnt for 25-30 years before these experimental burns. The 2 sites (Table 1 ) are part of a multidisciplinary study of fire modeling and impacts of tussock burning on plant and invertebrate communities and were chosen as representatives of higher- and lower-altitude tussock grassland environments in Otago, New Zealand. Data on impacts of fire on the vegetation at these sites are used to assist with interpretation of the microarthropod data.

Previous work at these sites has demonstrated that summer burning had a greater impact on Coleoptera than the spring burn, Coccinellidae and Curculionoidea appearing to be the most susceptible families (Barratt et al. 2003). Ferguson et al. (2003) reported on immediate postburn impacts of the fire at the invertebrate order level and found that although the abundance of some groups was considerably reduced after burning, very few were not represented at all when sampled after the fires. The objective of this study was to investigate the impacts of burning tussock grassland in spring and summer on mite and Collembola abundance at 2 tussock grassland sites.

\section{METHODS}

\section{Sites and Experimental Design}

The study sites were at Deep Stream (DS) and Mount Benger $(\mathrm{MB})$ in the Otago tussock grassland (South Island of New Zealand). These sites were chosen as typical examples of 
Table 1. Site descriptions, and dates of burning treatments and sampling.

\begin{tabular}{|c|c|c|}
\hline & Deep stream & Mount Benger \\
\hline Tenure & $\begin{array}{l}\text { Dunedin City Council } \\
\text { water reserve }\end{array}$ & Benger Pastoral Lease \\
\hline Altitude (m.a.s.I.) & 700 & 1100 \\
\hline Map reference & Lat $45^{\circ} 44^{\prime} \mathrm{S}$, long $169^{\circ} 54^{\prime} \mathrm{E}$ & $\begin{array}{l}\text { Lat } 45^{\circ} 58^{\prime} \text { 'S, long } \\
\quad 169^{\circ} 26^{\prime} \mathrm{E}\end{array}$ \\
\hline \multirow[t]{2}{*}{ Dominant vegetation } & $\begin{array}{l}\text { Chionochloa rigida } \\
\text { Gaultheria nana } \\
\text { Poa pratensis }\end{array}$ & $\begin{array}{l}\text { Chionochloa rigida } \\
\text { Poa colensoi } \\
\text { Polytrichum } \\
\quad \text { juniperinum }\end{array}$ \\
\hline & Poa colensoi & Agrostis capillaris \\
\hline Slope and aspect & $<10^{\circ}$ predom. $\mathrm{N}$ & $\begin{array}{l}2 \text { plots flat; } 1 \text { plot } \\
\quad<20^{\circ} \mathrm{S}\end{array}$ \\
\hline Annual rainfall (mm) & $\sim 600$ & $700-800$ \\
\hline Soil type & $\begin{array}{l}\text { Wehenga silt loam Upland } \\
\text { YBE (Typic Dystrudepts) }\end{array}$ & $\begin{array}{c}\text { Carrick Upland YBE BAM } \\
\text { (Dystric Cryochrept) }\end{array}$ \\
\hline Soil pH & 4.6 & 4.6 \\
\hline Date of spring burn & 2 October 2001 & 3 November 2000 \\
\hline Date of summer burn & 7 March 2001 & - \\
\hline Sample dates & $\begin{array}{l}\text { January } 2001 \\
\text { - } 9 \text { months pre- } \\
\text { spring burn } \\
\text { - } 2 \text { months pre- } \\
\text { summer burn } \\
\text { January } 2002 \\
\text { - } 3 \text { months post- } \\
\text { spring burn } \\
\text { - } 10 \text { months post- } \\
\text { summer burn } \\
\text { January } 2003 \\
\text { - } 15 \text { months post-spring burn } \\
\text { - } 22 \text { months post- } \\
\text { summer burn }\end{array}$ & $\begin{array}{l}\text { January } 2000 \\
\text { - } 10 \text { months preburn } \\
\text { January } 2001 \\
\text { - } 2 \text { months postburn } \\
\text { January } 2002 \\
\text { - } 14 \text { months postburn } \\
\text { January } 2003 \\
\text { - } 26 \text { months postburn }\end{array}$ \\
\hline
\end{tabular}

a lower- and relatively higher-altitude grassland prevalent in this region. Details of the sites are shown in Table 1. At both sites, experimental burning treatments have been carried out to simulate a managed spring burn at a time when the soil and vegetation would be relatively moist. A summer burn in hot, dry conditions, more typical of an accidental grassland fire, was carried out at DS. Each burning treatment was replicated 3 times at each site on 1-ha square plots that were burnt in either spring or summer or remained unburnt (control). There were, therefore, 9 plots at each site, although the summer burn treatment had not been carried out at MB. Each of the 1-ha plots were subdivided into $20 \times 20$-m subplots. One subplot in each replicate (excluding subplots at the periphery) was selected randomly and used for invertebrate sampling.

\section{Invertebrate Sampling}

On each sample date, 20 samples, $31.7 \times 31.7 \mathrm{~cm}\left(0.1 \mathrm{~m}^{-2}\right)$, were taken to a depth of approximately $5 \mathrm{~cm}$ from intertussock vegetation. The samples were taken from random positions along 4 rows, with 5 turves from each row, avoiding positions where a sample had been taken previously. The samples were
Table 2. Taxonomic groups of Acari and Collembola identified; mean densities in untreated plots in January 2001, 2002 and 2003; and percentage representation of each group.

\begin{tabular}{lcc}
\hline & Deep stream & Mount Benger \\
\cline { 2 - 3 } & No. $\cdot \mathrm{m}^{-2}(\%)$ & No. $\cdot \mathrm{m}^{-2}(\%)$ \\
\hline Acari & & \\
$\quad$ & & \\
Astigmata & $182 \pm 62(1)$ & $92 \pm 13(1)$ \\
Mesostigmata & $4783 \pm 647(36)$ & $3058 \pm 407(24)$ \\
Cryptostigmata (Oribatida) & $6711 \pm 700(50)$ & $7943 \pm 2187(62)$ \\
Prostigmata & $1689 \pm 373(13)$ & $1783 \pm 1070(14)$ \\
Total Acari & $13373 \pm 1462$ & $12876 \pm 1475$ \\
Collembola & & \\
Entomobryidae & $542 \pm 193(10)$ & $1173 \pm 380(16)$ \\
Isotomidae & $4135 \pm 637(79)$ & $4071 \pm 1232(54)$ \\
Onychuridae (Poduroidea) & $182 \pm 74(4)$ & $872 \pm 78(12)$ \\
Other Poduroidea & $350 \pm 105(7)$ & $1114 \pm 540(15)$ \\
Smithuridae & $34 \pm 12(1)$ & $307 \pm 110(4)$ \\
Total Collembola & $5243 \pm 2043$ & $7537 \pm 3766$ \\
Total microarthropods & $18579 \pm 2427$ & $20413 \pm 4077$ \\
\hline
\end{tabular}

taken by placing a quadrat frame on the ground and cutting around it to a depth of $3-5 \mathrm{~cm}$ with a spade and then cutting horizontally to remove the turf intact. Turves were bagged individually in paper sacks and returned to the laboratory for processing. The sampling dates are shown in Table 1.

Invertebrates were extracted from individual turves in heat extraction funnels over a 5-7-day period using 150 -W lightbulbs positioned $40 \mathrm{~cm}$ above the intact inverted samples (Crook et al. 2004). The extracted invertebrates were stored in $70 \%$ ethanol with $10 \%$ glycerol until counts were carried out. For identification, each individual sample was placed in a funnel lined with fine muslin and washed through with water to remove very fine particulate matter. The invertebrates retained were sorted under a binocular microscope, all meso- and macroinvertebrates were removed from the samples, and the remaining microarthropods were placed in an 84 -mm-diameter Petri dish marked in a grid with $6.5 \times 6.5$ - $\mathrm{mm}$ squares. There were 144 squares in total (including incomplete squares from the perimeter), and Collembola and mites were identified to family/superfamily (Table 2) and counted from 12 randomly selected complete squares. Data were converted to density per square meter.

\section{Statistical Analysis}

A repeated-measures analysis of variance (ANOVA) was considered for these data, but the assumption of independence of the observations and equal variance from one year to the next could not be reliably tested given the degree of replication that was possible in the experiment. For the same reason, the assumption of equal variance from site to site could not be reliably tested. A conservative approach therefore dictated that it was unwise to assume that these required assumptions would be true. Consequently, 1-way ANOVA of the 3 replicates of 3 treatments was carried out on the density measures from the 9 subplots in order to determine treatment effects and to obtain standard errors of mean density (SEs). 

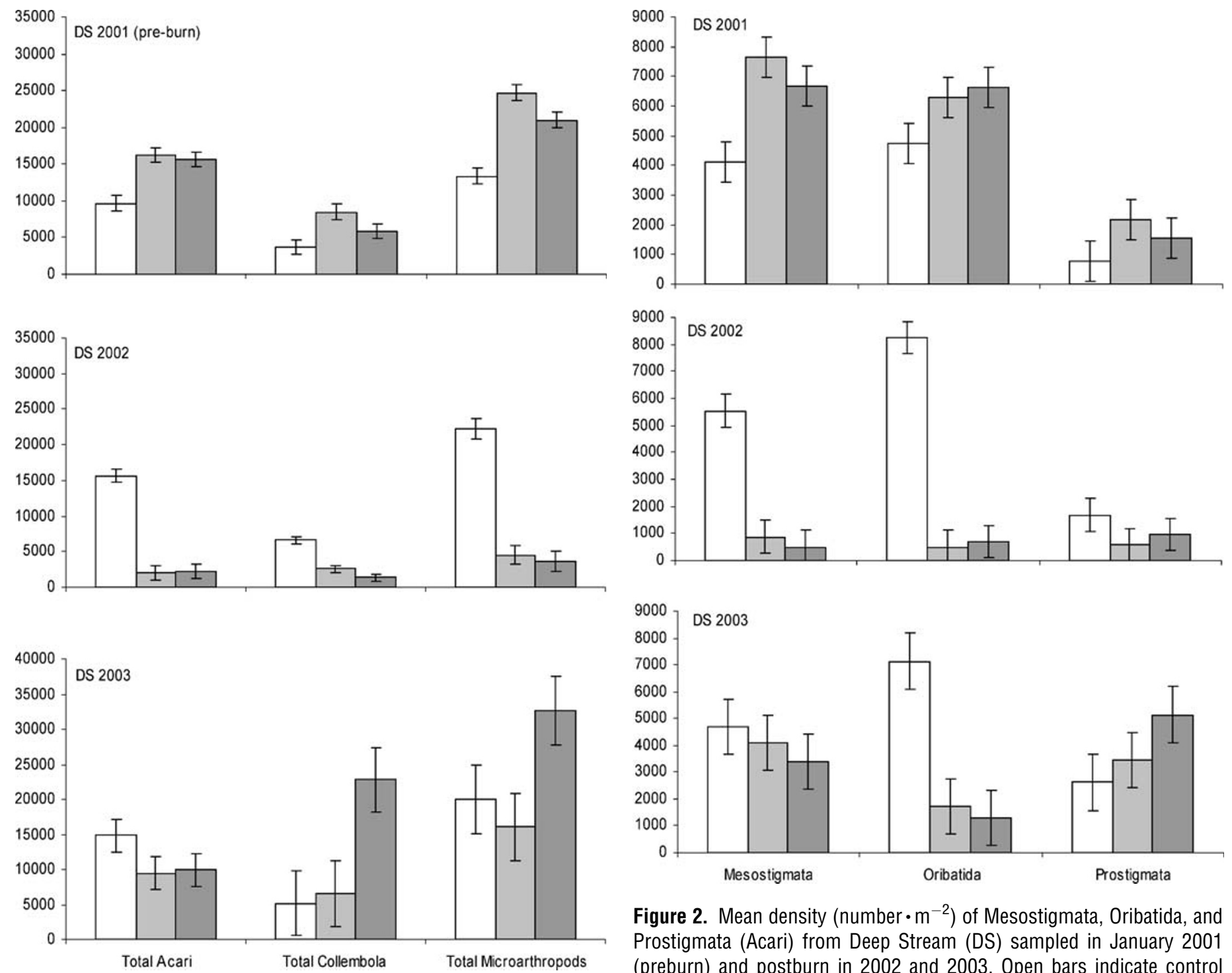

Figure 2. Mean density (number $\cdot \mathrm{m}^{-2}$ ) of Mesostigmata, Oribatida, and Prostigmata (Acari) from Deep Stream (DS) sampled in January 2001 (preburn) and postburn in 2002 and 2003. Open bars indicate control plots; light bars, spring-burn plots; dark bars, summer-burn plots. Error bars represent 2 standard errors.

Figure 1. Mean density (number $\cdot \mathrm{m}^{-2}$ ) of Acari, Collembola, and total (preburn) and postburn in 2002 and 2003. Open bars indicate control plots; light bars, spring-burn plots; dark bars, summer-burn plots. Error bars represent 2 standard errors.

For a comparison of the microarthropod fauna at the 2 sites, mean densities $( \pm$ SE) of taxa across 3 years (January 2001, 2002, and 2003) for the control subplots were calculated.

\section{RESULTS}

The taxonomic composition and total abundance of the mite and collembolan fauna at the 2 sites was quite similar, especially for Acari (Table 2). At both sites, the Mesostigmata and Oribatida were the most abundant mite families. Isotomidae were the most abundant collembolan family at both sites, although this group did not dominate at $\mathrm{MB}$ as it did at DS ( $54 \%$ vs. $79 \%$ of total density, respectively). At DS and MB, these 3 families numerically comprised approximately $84 \%$ and $74 \%$, respectively, of the total microarthropod fauna.

\section{Deep Stream}

Total microarthropods extracted from turves at DS ranged from $13000 \mathrm{~m}$ to $22000 \cdot \mathrm{m}^{-2}$ in the control subplots over the 3 years of the study. However, there were significantly more microarthropods $(P<0.001)$ in total in both subplots designated to be burnt in spring and summer than in the control subplots (Fig. 1) even before the burn took place. In the subplots to be burnt in spring, densities of both mites and Collembola were significantly higher than in the control subplots $(P=0.01 ; P<0.05$, respectively) (Fig. 1$)$, resulting mainly from significantly higher densities of Mesostigmata $(P<0.05)$ (Fig. 2). Seven months before the summer burn was carried out, the total density of mites was significantly higher than in the control subplots, attributable mainly to higher densities of Mesostigmata $(P<0.05)$ (Fig. 2).

In January 2002, 3 months after the spring burn and 10 months after the summer burn at DS, total microarthropod densities were significantly reduced to $4500 \cdot \mathrm{m}^{-2}$ (spring burn, $P<0.001$ ) and $3600 \cdot \mathrm{m}^{-2}$ (summer burn, $P<0.001$ ) 
compared with the mean density in the unburnt subplots of $22000 \cdot \mathrm{m}^{-2}$ (Fig. 1). Both mite and Collembola densities were reduced in both treatments, particularly Mesostigmata $(P<0.01)$ and Oribatida $(P<0.001)$ (Fig. 2$)$ and Isotomidae $(P<0.001)$ (Fig. 3). However, by January 2003, total microarthropod densities had increased to levels where they were not significantly different from the unburnt subplots, which had changed very little from the previous year (Fig. 1). The density of Collembola was higher in the summer burn subplots in January $2003(P=0.067)$ as a result of high densities of Poduroidea up to almost $14000 \cdot \mathrm{m}^{-2}$ (Fig. 3) compared with densities in the control subplots that did not exceed $5000 \cdot \mathrm{m}^{-2}$ in any year. However, because of the large variability in density of this group between the 3 replicate subplots $(2$ 200, 6200 , and $33000 \cdot \mathrm{m}^{-2}$ ), these increases were not significant. The density of Oribatida, which was considerably reduced after both the spring and the summer burns in 2002, were still significantly reduced in $2003(P<0.001)$ (Fig. 2). However, the densities of Mesostigmata, which were also reduced in comparison with the unburnt subplots following both the spring and the summer burns, appeared to have recovered by January 2003 but did not exceed densities in the control subplots as they had done preburn in January 2001.

\section{Mount Benger}

Total microarthropod densities in the control subplots were comparatively consistent in the first 3 years, ranging from $13000 \cdot \mathrm{m}^{-2}$ to $19000 \cdot \mathrm{m}^{-2}$, but reached almost $32000 \cdot \mathrm{m}^{-2}$ in 2003 (Fig. 4). In January 2000, before the spring burn took place, total densities of mites, Collembola, and hence total microarthropods were similar in both experimental subplots.

Two months after the spring burn, total microarthropod density was significantly reduced $(P<0.05)$ (Fig. 4), mainly as a result of combined reductions in densities of Oribatida (Fig. 5) and Isotomidae (Fig. 6), although neither were significant. Only the density of Mesostigmata were significantly reduced by the spring burn $(P<0.05)$ (Fig. 5). However, by January 2002, there was no significant difference in total microarthropod densities despite the total density of mites being significantly reduced $(P<0.05)$ (Fig. 4), a result mainly of the reduction in the density of Oribatida $(P<0.01)$ (Fig. 5). The higher densities of Poduroidea and Smithuridae were not significantly different from those in the control subsubplots. By January 2003, 26 months after the spring burn treatment, the total density of mites was similar to that of the unburnt subplots, although the mean density of the Oribatida in the burnt subplots remained significantly reduced $(P<0.05)$ (Fig. 5). There was also no difference in total densities of Collembola between the 2 treatments (Fig. 4). The density of the 3 groups, Isotomidae, Poduroidea, and Sminthuridae, remained comparatively high in 2003, but again these differences were not significant because of subplot variability (Fig. 6).

\section{DISCUSSION}

This study was a structured, replicated, pre- and postburn comparison of microarthropods sampled quantitatively using relatively large unit sample sizes. The total density of microarthropods at these sites was moderate compared with densities
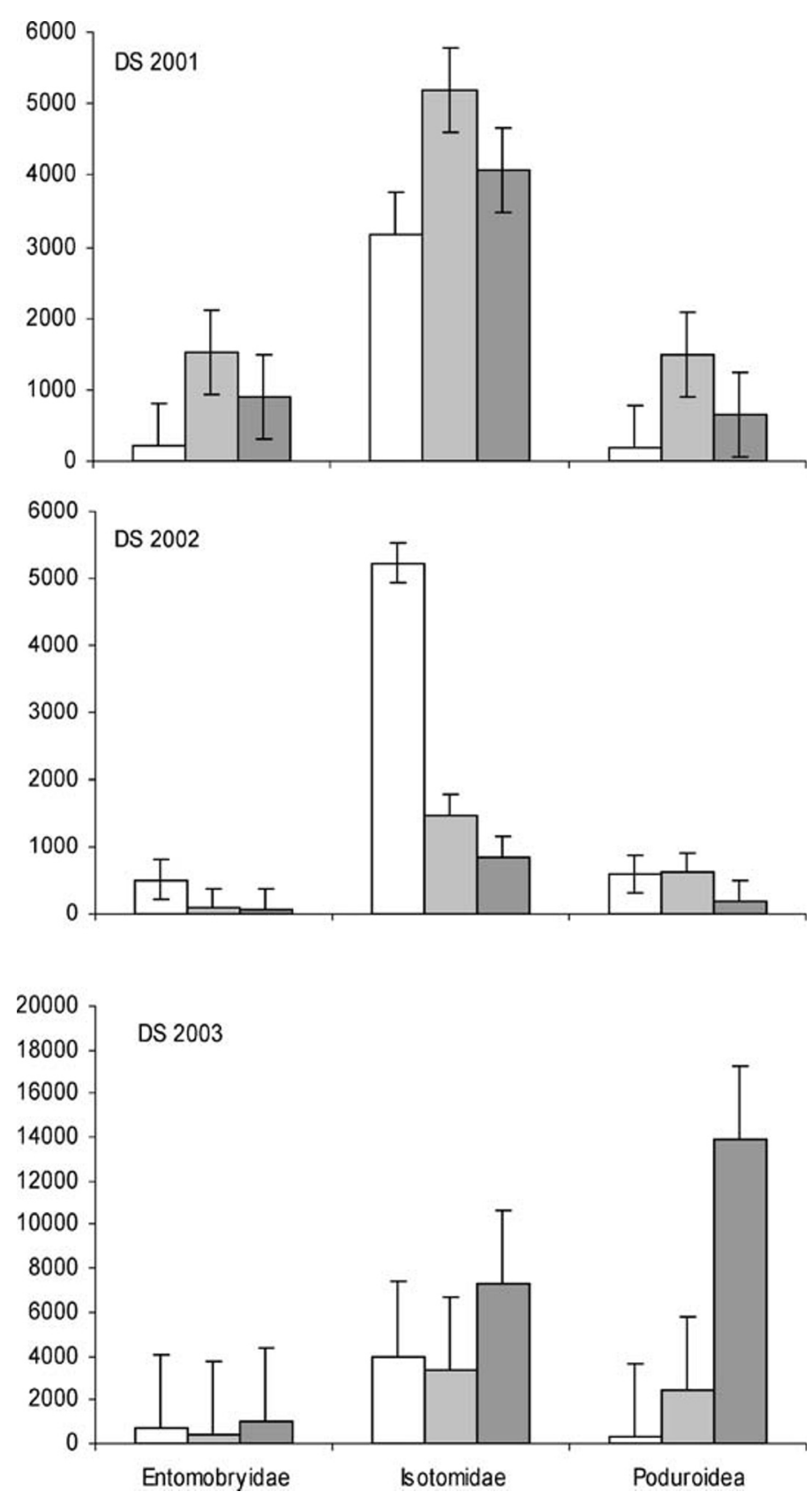

Figure 3. Mean density (number $\cdot \mathrm{m}^{-2}$ ) of Entomobryidae, Isotomidae, and Poduroidea (Collembola) from Deep Stream (DS) sampled in January 2001 (preburn) and postburn in 2002 and 2003. Open bars indicate control plots; light bars, spring-burn plots; dark bars, summerburn plots. Error bars represent 2 standard errors for 2001 and 2002; 1 standard error for 2003 for clarity. Note density scale for 2003 not the same as for 2001 and 2002.

that can be reached in unmanaged and natural grassland. Populations of Acari can exceed $100000 \cdot \mathrm{m}^{-2}$ in such conditions, and Collembola population densities range from a few thousand to $100000 \cdot \mathrm{m}^{-2}$ in old grassland in Northern Europe (Curry 1987a, 1987b).

Warren et al. (1987) distinguished between acute (during and immediately after the fire) and chronic impacts of burning. Chronic impacts occur during the vegetation recovery phase until equilibrium between floral and faunal populations is 

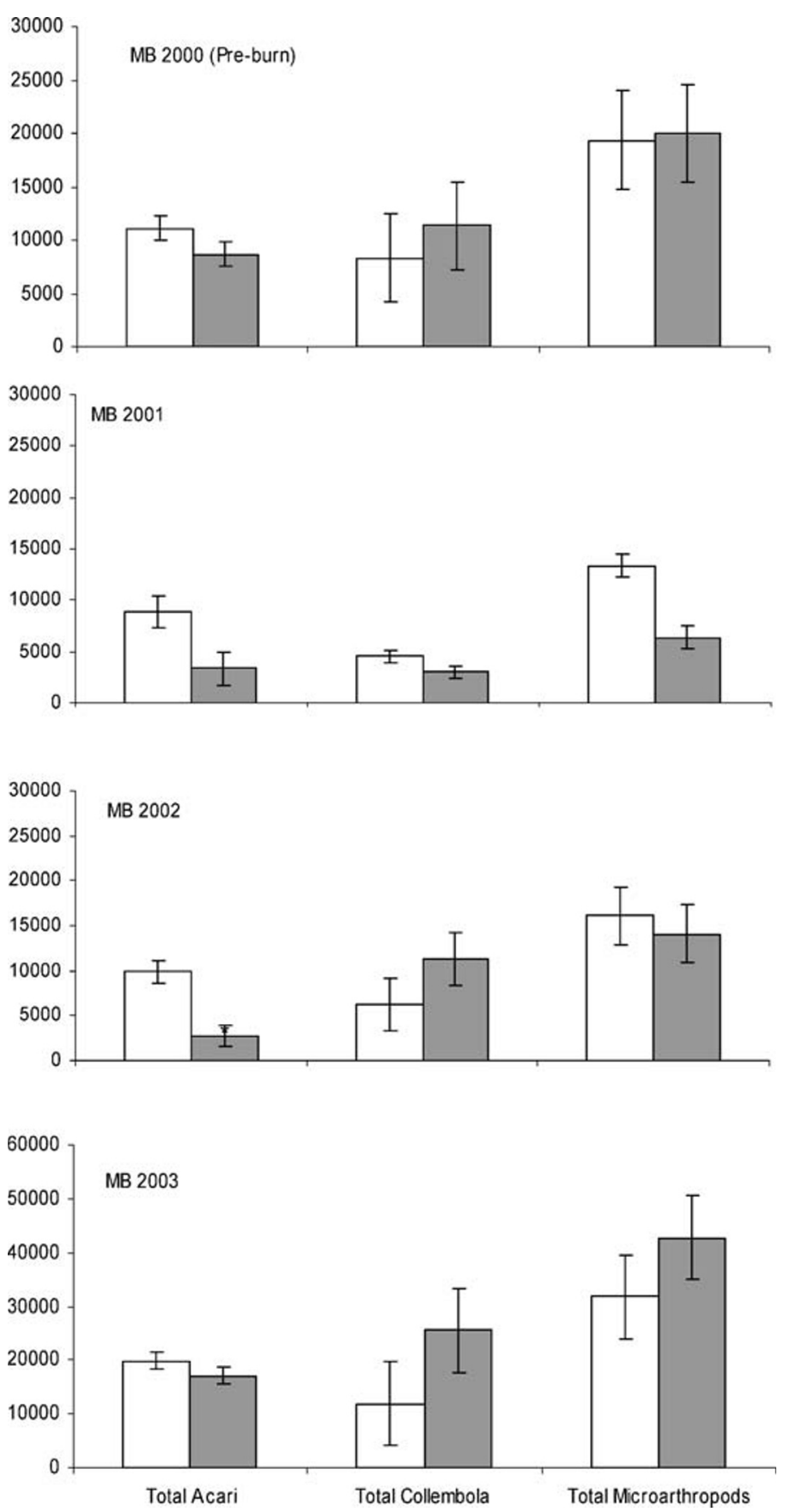

Figure 4. Mean density (number $\cdot \mathrm{m}^{-2}$ ) of Acari, Collembola, and total microarthropods from Mount Benger (MB) sampled in January 2000 (preburn) and postburn in 2001, 2002, and 2003. Open bars indicate control plots; shaded bars, spring-burn plots. Error bars represent 2 standard errors. Note density scale for 2003 not the same as for 2000 , 2001, and 2002.

reached. Most of the acute impacts on grassland arthropods are affected by a complex of factors and fire characteristics such as timing of the burn in relation to phenology; postburn weather; size of burned area; quantity, size, water content, and chemistry of accumulated fuel; weather conditions during the burn; topography; and so on, all of which influence fire intensity, rate of spread, and uniformity of the burn (Warren et al. 1987). Heat-sensitive paints used for temperature mea-

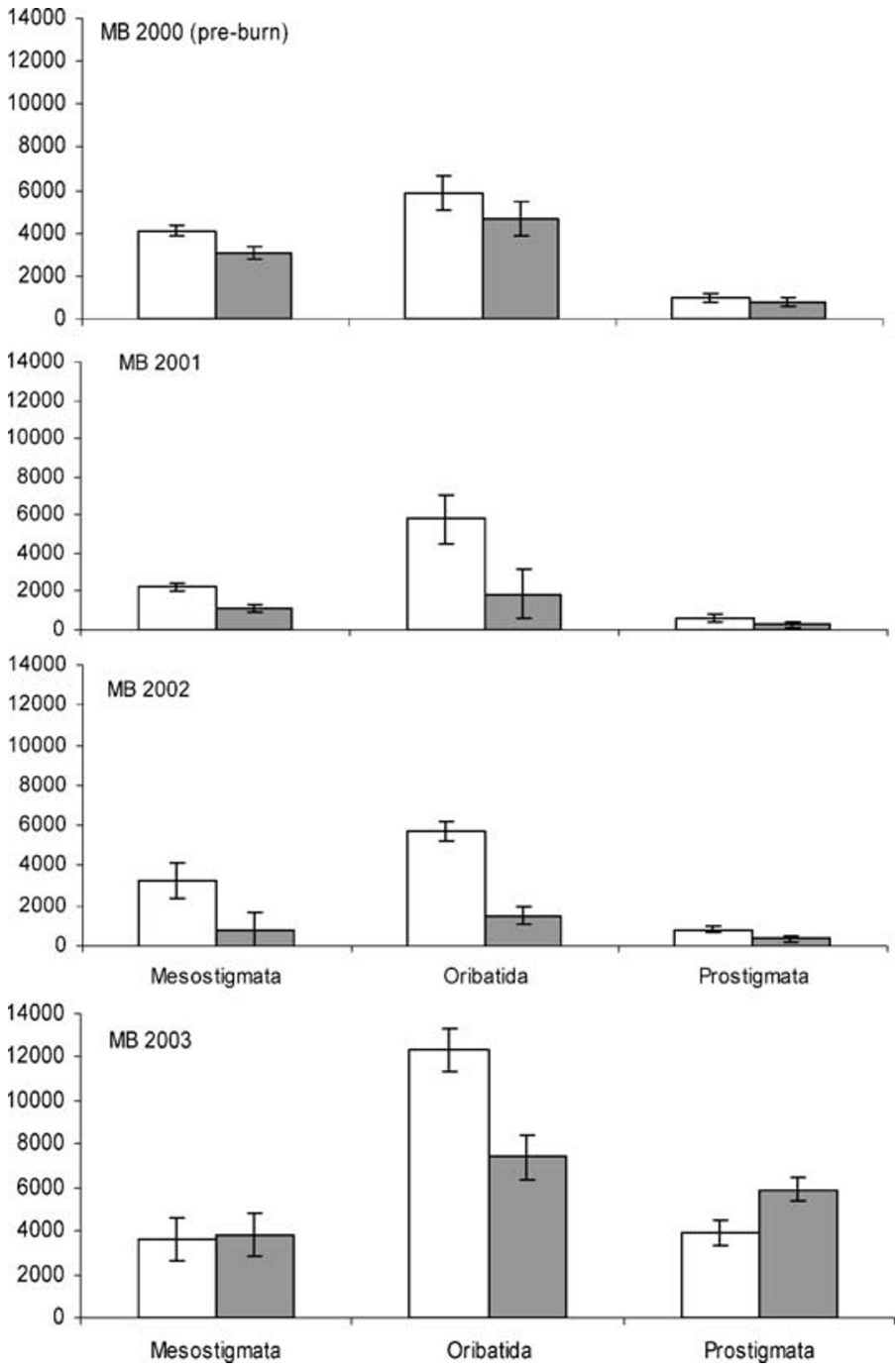

Figure 5. Mean density (number $\cdot \mathrm{m}^{-2}$ ) of Mesostigmata, Oribatida and Prostigmata (Acari) from Mount Benger (MB) sampled in January 2000 (preburn) and postburn in 2001, 2002, and 2003. Open bars indicate control plots; shaded bars, spring-burn plots. Error bars represent 2 standard errors.

surements at the time of the DS and $\mathrm{MB}$ fires indicated that temperatures at the soil surface reached $500^{\circ}-1010^{\circ} \mathrm{C}(\mathrm{MB}$ and DS spring burns) and $300^{\circ}-500^{\circ} \mathrm{C}$ (DS summer burn) at the surface and in all cases $<69^{\circ} \mathrm{C}$ at $2.5-\mathrm{cm}$ depth (NZ Fire Research 2001), so clearly a dramatic heat gradient was established as the fire moved across the vegetation. Thermocouple measurements showed that at the surface temperatures remained at their peak for 45-74 seconds and tailed off over the following 10-15 minutes (NZ Fire Research 2001). Webb (1994) measured soil temperatures during a heathland fire and found that at $0-3 \mathrm{~cm}$ below the surface, the temperature reached about $65^{\circ} \mathrm{C}$ but only for about 2 minutes. The author suggested that although $41^{\circ}-42^{\circ} \mathrm{C}$ was determined as lethal for an oribatid species, for short periods they can probably survive higher temperatures, and hence few animals were killed directly by fire but rather by changes in microclimate resulting from fire. In our study, with higher surface temperatures reached, temperatures at the surface and down to $2-3 \mathrm{~cm}$ may have been considerably 
higher than lethal temperatures for most microarthropods, and hence acute impacts at this level may have been relatively high.

The preburn aboveground vegetation biomass at DS and MB were similar at about $27000-29000 \mathrm{~kg} \cdot \mathrm{ha}^{-1}$, respectively, of which about $60 \%$ and $68 \%$, respectively, was litter (Payton and Pearce 2001). The spring burn at MB removed an average of $32 \%$ of aboveground biomass and left much of the groundcover vegetation intact. However, the spring burn at DS removed $70 \%$ of aboveground biomass, including most of the litter and ground-cover vegetation. This difference was attributed to the higher moisture content of tussock bases and upper soil layers at MB compared with DS (Payton and Pearce 2001). The summer burn at DS removed $74 \%$ of the aboveground biomass and most of the litter, but compared with the spring burns, the recovering vegetation was exposed to winter frosts soon after the burning treatment (Payton 2003). Fire Weather Index data (Van Wagner 1987) of particular significance to microarthropods was the Duff Moisture Code (DMC). This is an index of the moisture content of the layer of partially and fully decomposed organic materials lying below the undecomposed litter layer and immediately above the mineral soil, where a DMC range of 0 30 denotes minimal to high fire risk. The DMC for the MB spring burn was 6 compared with 14 and 26 for the DS spring and summer burns, respectively. The retention of more ground cover at MB compared with both DS burns and the higher duff moisture content probably contributed to the apparently more significant impacts of the fires on microarthropod densities at DS. Henig-Sever et al. (2001) found a negative correlation between fire intensity and microarthropod density and composition of the community. While we anticipated a more intense fire during summer than spring at DS, using plant biomass removal and $\mathrm{DMC}$ as indicators and in comparison with the $\mathrm{MB}$ spring burn, it would appear that the spring burn at DS was probably more intense than would be expected at this time of year. This may have contributed to the apparent similarity of the impacts of fire on microarthropods at DS in both seasons.

The impacts on the microarthropod fauna measured at DS were more pronounced in the year following the spring burn than at $\mathrm{MB}$, probably resulting from the difference in impacts of the fire on the vegetation and litter mentioned previously. Nevertheless, at both sites the Oribatida were significantly reduced in density for 2 successive years postburn. Conversely, after initial reductions in densities of Isotomidae and Poduroidea in the year following spring burning treatments at both sites, there is evidence that the densities of these groups increased in the second year. Prostigmata appeared to be unaffected by fire, concurring with Seastedt (1984), who found that Oribatida, Mesostigmata, and collembolans were reduced in density by fire but that Prostigmata were not significantly affected by burning. Warren et al. (1987) suggested that some Prostigmata are found deeper in the soil profile and hence might escape lethal temperatures at the soil surface. Most Collembola feed on decaying organic matter and are sensitive to changes in soil moisture and hence to burning. Population reductions have been attributed to removal of litter, darkened soil and increased insolation, and greater evaporation, which reduces soil moisture (Van Amburg et al. 1981; Seastedt 1984).

Comparing the impact of the spring and summer fires at DS, given that similar levels of plant and litter biomass removal were measured, one might expect that the dry summer con-
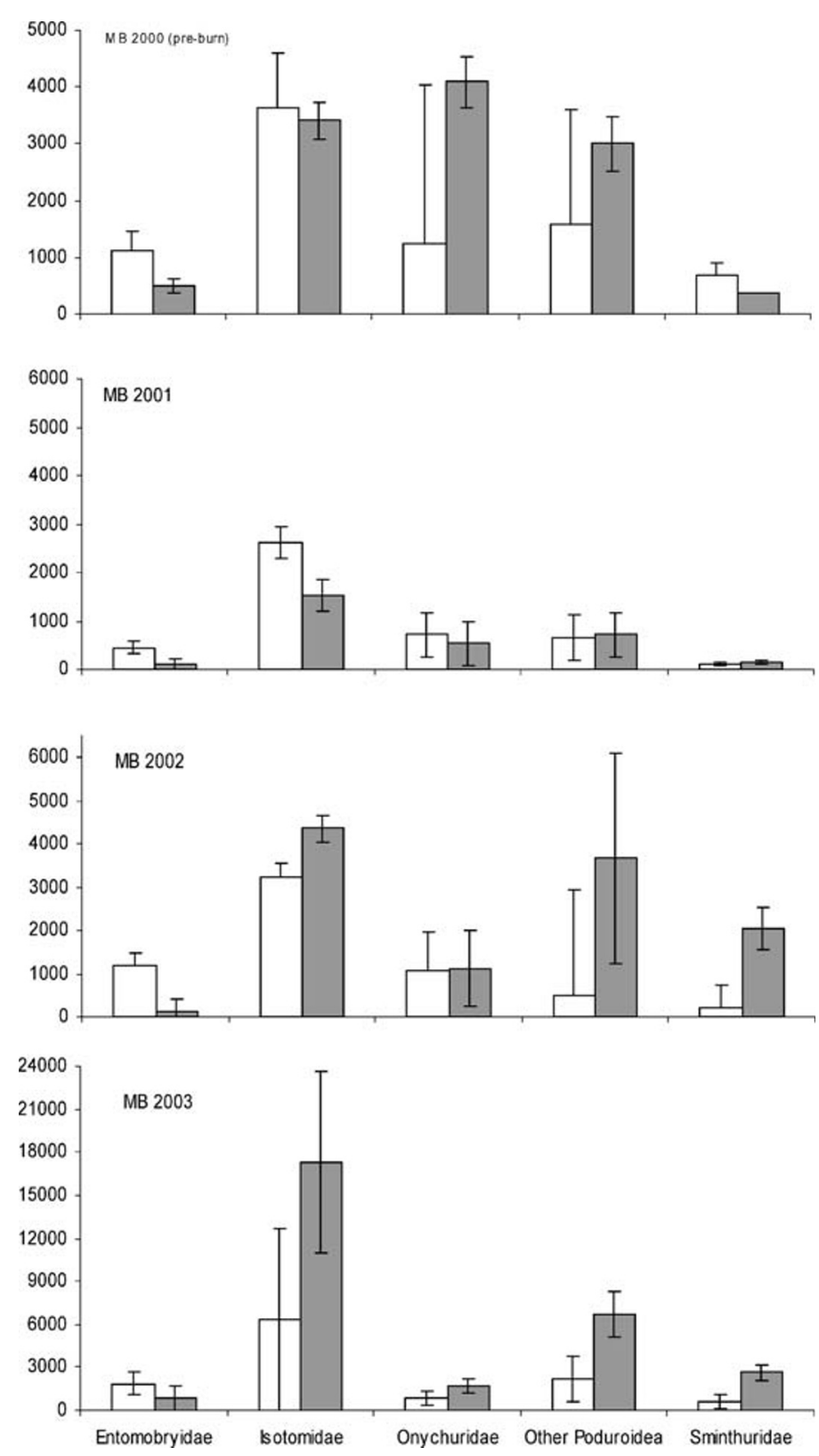

Figure 6. Mean density (number $\cdot \mathrm{m}^{-2}$ ) of Entomobryidae, Isotomidae, Onychuridae, other Poduroidea, and Sminthuridae (Collembola) from Mount Benger (MB) sampled in January 2000 (preburn) and postburn in 2001, 2002 and 2003. Open bars indicate control plots; shaded bars, spring-burn plots. Note density scale for 2003 not the same as for 2000 , 2001, and 2002. Error bars represent 2 standard errors except for the 2000 and 2002 control subplots, where 1 standard error is shown for clarity.

ditions following the spring burn might have a greater impact on microarthropods than the summer burn, which occurred late in the season and was followed by cooler, moist conditions. However, the effects of spring and summer burning on microarthropod densities were rarely different from each other despite the very variable data for Poduroidea in 2003. Some families of Poduroidea (e.g., Hypogastruridae) are well known for extreme aggregations in population distribution (Hopkin 1997), which might account for the highly variable data for Poduroidea recorded in these plots. Alternatively, such an effect 
may have arisen as a result of differential impacts of the fire on predators. Clearly, the impact of a major environmental disturbance such as fire on a particular component of the fauna cannot be interpreted in isolation from the impacts on the entire community. Given our very incomplete understanding of the trophic structure of the tussock grassland invertebrate community and of the interactions of the biota with abiotic factors, considerably more research will be required before full interpretation of the chronic impacts of burning is possible.

\section{MANAGEMENT IMPLICATIONS}

The results for up to 26 months after burning indicated that population densities of some groups were initially and quite substantially reduced, probably in direct response to the high temperatures of the fire, and subsequently in response to destruction of the soil surface litter layer, which provides refuge and a food supply for many microarthropod groups. However, by the end of the study, population densities of these groups had recovered and indeed exceeded preburn abundance in some cases. Longer-term sampling would be required in order to determine the time required for these microarthropod communities to equilibrate after the effects of the major disturbance to the environment caused by fire and to ascertain the extent to which community structure will change in response to inevitable changes in vegetation composition, and the meso- and macroarthropod communities with which they interact.

It would be unrealistic to expect that decisions on native grassland management will depend entirely on potential impacts of fire on microfauna despite the crucial role that these communities play in this ecosystem. However, land managers concerned about the impact that fire might have on the ecologically valuable soil biota can observe from the data presented that abundance of these groups can be spatially and temporally quite variable even in the absence of fire.

Within the context of normal practice in grazed rangeland in New Zealand, DS and MB have remained unburnt (approximately 30 and 25 years, respectively) for probably longer than average. In their Code of Practice, which provides guidelines for farmers, the Otago Regional Council (2002) notes that vigorous tussock provides protection against soil erosion and invasive weeds, and so burning should be regarded as a "management tool of last resort." They acknowledge, however, that burning is sometimes necessary to reduce fuel load. Burning during winter and spring is recommended to reduce adverse impacts on vegetation, and 1 full growing season should elapse before grazing. The Code recommends 12-20 years between burns for improved tussock grassland in the climatic zones where the MB and DS sites are located, but for unimproved grassland, such as at $\mathrm{MB}$ and $\mathrm{DS}$, decisions should be made on a case-by-case basis, depending on a fire recovery index that takes into account tussock plant density and tiller length and biomass (Otago Regional Council 2002).

Increasing areas of native grassland in New Zealand are being managed by the Department of Conservation, where values may be quite different from those of farmers. However, conservation management might provide for burning, for example, to prevent succession to shrubland or to reduce fuel load. Conservation land managers also have to make rapid decisions on deployment of resources to deal with accidental fires, and so information on seasonal differences in impacts and time since previous fire could be factors that would affect potential impacts on the grassland ecosystem. In this context the results from this study indicate rapid recovery of some microfaunal populations after fire that is not strongly influenced by seasonal effects.

\section{ACKNOWLEDGMENTS}

We thank Landcare Research, the NZ Foundation for Research Science and Technology, and the NZ Department of Conservation for funding this research; the Dunedin City Council, Alan Michelle, and John Deans for access to the experimental sites; Dr Penny Greenslade for assistance with identification of Collembola; Dr Owen Seeman (Queensland Museum) for assistance with mite identification; and Dr Upali Sarathchandra (AgResearch, Ruakura) and Dr Peter Espie for soil and vegetation data.

\section{LITERATURE CITED}

AsPINAL, J. H. 2001. Issues around use of fire as a land management tool in rural New Zealand. In: G. Pearce and L. Lester (EDS.). Bushfire 2001. Joint Bushfire/ FRFANZ Conference, Christchurch: New Zealand Forest Research Institute. p. 237-242.

Barratt, B. I. P., C. M. Ferguson, R. A. S. Logan, T. J. Murray, and K. J. M. DICKINSON. 2003. Impact of burning on Coleoptera, particularly Curculionoidea, in New Zealand native tussock grassland. Invertebrate Biodiversity and Conservation Records of the South Australia Museum Monograph Series No. 7:171-178.

Blanche, K. R., A. N. Anderson, and J. A. Ludwig. 2001. Rainfall-contingent detection of fire impacts: responses of beetles to experimental fire regimes. Ecological Applications 11:86-96.

Chahartaghi, M., R. Langel, S. Scheu, and L. Ruess. 2005. Feeding guilds in Collembola based on nitrogen stable isotope ratios. Soil Biology and Biochemistry 37(9):1718-1725.

Coleman, D. C., D. A. Crossley, and P. F. Hendrix. 2004. Fundamentals of soil ecology. Amsterdam: Elsevier Academic Press.

Coupland, R. T. (ED.) 1992. Natural grasslands: Introduction and Western Hemisphere. Amsterdam: Elsevier. 469 p.

Crook, K. E., C. M. Ferguson, and B. I. P. Barratt. 2004. Heat extraction of invertebrates from grassland turf samples. In: L. M. Winder and S. L. Goldson (EDS.). Proceedings of the 8th Australasian Conference on Grassland Invertebrate Ecology; 1-4 June 2004; Christchurch: AgResearch Ltd, Lincoln, New Zealand. p. 102-106.

Curry, J. P. 1987a. The invertebrate fauna of grassland and its influence on productivity. I. The composition of the fauna. Grass and Forage Science 42:103-120.

CuRRY, J. P. 1987b. The invertebrate fauna of grassland and its influence on productivity. II. Factors affecting the abundance and composition of the fauna. Grass and Forage Science 42:197-212.

Ferguson, C. M., R. A. S. Logan, B. I. P. Barratt, and P. D. Johnstone. 2003. Impacts of burning on native tussock grassland invertebrates in Otago, New Zealand. In: A. D. Austin, D. A. Mackay, and S. J. B. Cooper (EDS.). Invertebrate biodiversity and conservation. Adelaide: South Australian Museum, Adelaide. p. 163-169.

FloAte, M. J. S. 1992. Guide to tussock grassland farming. Mosgiel, New Zealand: AgResearch. 127 p.

Friend, G. 1996. Fire ecology of invertebrates-implications for nature conservation, fire management and future research. In: Proceedings of the Fire and Biodiversity Conference, 1994. Biodiversity Series, Paper Number 8. Canberra, Australia: Biodiversity Unit, Department of Environment, Sport and Territories. p. $155-162$.

Henig-Sever, N., D. Poliakov, and M. Broza. 2001. A novel method for estimation of 
wild fire intensity based on ash $\mathrm{pH}$ and soil microarthropod community. Pedobiologia 45:98-106.

HopkIN, S. P. 1997. Biology of the springtails (Insects: Collembola). Oxford: Oxford University Press. 330 p.

LoWTHER, W. L., AND M. H. Douglas. 1992. Pasture establishment and development. In: M. J. S. Floate (ED.). Guide to tussock grassland farming. Mosgiel, New Zealand: AgResearch. p. 55-60.

MaRK, A. F. 1965. Effects of management practices on narrow-leaved snowtussock. New Zealand Journal of Botany 3:300-319.

MARK, A. F. 1993. Indigenous grasslands of New Zealand. In: R. T. Coupland (ED.). Natural grasslands Eastern Hemisphere and resume. Amsterdam: Elsevier. p. $361-410$.

McEwEN, W. M. (ED.) 1987. Ecological regions and districts of New Zealand: Third revised edition in four 1:500 000 maps. Wellington: New Zealand Biological Resources Centre, Publication No. 5, New Zealand Department of Conservation. 4 Vols. accompanying 4 maps.

NZ FiRe Research 2001. Fire research update. Newsletter of the Forest and Rural Fire Research Programme. Christchurch: New Zealand Forest Research. $8 \mathrm{p}$.

O'Connor, K. F., and A. J. Powell. 1963. Studies on the management of snowtussock grassland. I The effects of burning, cutting and fertiliser on the narrow-leaved snow-tussock at a mid-altitude site in Canterbury. New Zealand Journal of Agricultural Research 6:354-367.

Otago Regional Councll. 2002. Code of practice for the management of vegetation burning in the Otago high country. Dunedin, New Zealand: Otago Regional Council. $61 \mathrm{p}$.

PaYton, I. J. 2003. What's new in fire research? In: R. Lough (ED.), High country seminar, Cromwell. Otago, New Zealand: Otago Regional Council. p. 47-51.

Payton, I. J., W. G. Lee, R. Dolby, and A. F. Mark. 1986. Nutrient concentrations in narrow-leaved snow tussock (Chionochloa rigida) after spring burning. New Zealand Journal of Botany 24:529-537.

Payton, I. J., and G. Pearce. 2001. Does fire deplete the physical and biological resources of tall-tussock (Chionochloa) grasslands? The latest attempt at some answers. In: G. Pearce and L. Lester (EDS.). Bushfire 2001. Joint Bushfire/FRFANZ Conference; 3-6 July 2001; Christchurch, New Zealand: New Zealand Forest Research Institute. p. 243-249.

RUSEK, J. 1998. Biodiversity of Collembola and their functional role in the ecosystem. Biodiversity and Conservation 7:1207-1219.

SEAStedt, T. R. 1984. Microarthropods of burned and unburned tallgrass prairie. Journal of the Kansas Entomological Society 57:468-476.

TscharntKe, T., AND H.-J. Greiler. 1995. Insect communities, grasses, and grasslands. Annual Review of Entomology 40:535-558.

Van Amburg, G. L., J. A. Swaby, and R. H. Pemble. 1981. Response of arthropods to a spring burn of a tallgrass prairie in northwestern Minnesota. Ohio Biological Survey Biological Notes Series 15:240-243.

Van WagneR, C. E. 1987. Development and structure of the Canadian Forest Fire Weather Index System. Forestry Technical Report 35. Ottawa, Ontario: Government of Canada, Canadian Forestry Service. $37 \mathrm{p}$.

Wardle, P. 1991. Vegetation of New Zealand. Cambridge: Cambridge University Press. $672 \mathrm{p}$.

Warken, S. D., C. J. Scifres, and P. D. Teel. 1987. Response of grassland arthropods to burning: a review. Agriculture, Ecosystems and Environment 19:105-130.

WeBB, N. R. 1994. Post-fire succession of cryptostigmatid mites (Acari, Cryptostigmata) in a Calluna-heathland soil. Pedobiologia 38:138-145.

Yeates, G. W., AND W. G. LeE. 1997. Burning in a New Zealand snow-tussock grassland: effects on vegetation and soil fauna. New Zealand Journal of Ecology 21:73-79. 